Western University

Scholarship@Western

Centre for the Study of International Economic Centre for the Study of International Economic

Relations Working Papers

Relations

1984

\title{
Simulating Commercial Policy in a Small, Open Dual Economy with Urban Unemployment: A General Equilibrium Approach
}

Åke Blomqvist

Gary McMahon

Follow this and additional works at: https://ir.lib.uwo.ca/economicscsier_wp

Part of the Economics Commons

Citation of this paper:

Blomqvist, Åke, Gary McMahon. "Simulating Commercial Policy in a Small, Open Dual Economy with Urban Unemployment: A General Equilibrium Approach." Centre for the Study of International Economic Relations Working Papers, 8403C. London, ON:

Department of Economics, University of Western Ontario (1984). 
ISSN $\quad 0228-4235$

ISBN $\quad 0-7714-0492-1$

CENTRE FOR THE STUDY OF INTERNATIONAL ECONOMIC RELATIONS

WORKING PAPER NO. $8403 \mathrm{C}$

SIMULATING COMMERICAL POLICY IN A SMALL, OPEN DUAL ECONOMY

WITH URBAN UNEMPLOYMENT: A GENERAL EQUILIBRIUM APPROACH

\author{
Àke Blomqvist \\ and \\ Gary McMahon \\ JAN 17 1584
}

This paper contains preliminary findings from research still in progress and should not be quoted without prior approval of the author.

DEPARTMENT OF ECONOMICS

UNIVERSITY OF WESTERN ONTARIO

LONDON, CANADA

N6A $5 \mathrm{C} 2$ 
SIMULATING COMMERCIAL POLICY IN A SMALL, OPEN DUAL ECONOMY WITH URBAN UNEMPLOYMENT : A GENERAL EQUILIBRIUM APPROACH *

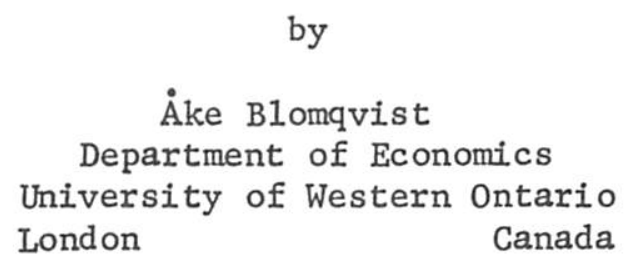

Gary McMahon Department of Economics

Laurentian University

Sudbury Canada

October 1983 


\section{Introduction}

Since the first formalizations of the rural-urban migration problem by Todaro (1969) and Harris and Todaro (1970), their models have been extensively used in attempts to analyze the probable consequence of various second-best policy interventions in LDCs which are characterized by urban unemployment due to a rigid wage in the manufacturing sector. In the openeconomy case, an interesting question in this context is the potential effectiveness of tariff policy as a tool for counteracting the effects of this labour market distortion. Analytical work has shown that in general, tariff policy can be used to obtain some efficiency improvement, though the proper way to use this policy instrument depends on the precise nature of the wage rigidity. Thus, the work of Srinivasan and Bhagwati (1975; henceforth denoted by SB) implied that if the wage in the manufacturing sector is constant in terms of the manufactured good, then a subsidy on imports of the manufactured good would be welfare-improving in a small open economy; on the other hand, Blomqvist (1979) showed that if the urban wage is determined primarily by the price of the agricultural good, then a positive tariff on the manufactured good would be the second-best commercial policy.

While the analytical work referred to above is potentially useful by giving an indication of one type of question that would need to be answered if the policy-makers were to seriously attempt to make practical use of this kind of second-best policy (namely, just how is the non-competitive wage determined?), there are several other important issues that must also be addressed before this should be done. One such issue concerns the way 
the effects of tariff policy would depend on the existence of other distortions in the economy (such as domestic taxes or subsidies). A second question would be whether, and to what extent, the earlier results concerning the effectiveness of second-best commercial policy would have to be modified if it is recognized that in reality, capital is mobile (at least to some extent) between economic sectors; most of the existing work in this area has been based on models in which it was assumed that capital was immobile. A third, and perhaps the most important, question would be the quantitative significance of the welfare gains from second-best commercial policy, in comparison with the welfare loss from the wage rigidity itself; if the former were small relative to the latter, the best policy strategy might be to concentrate on finding ways to make the labour market function more competitively, rather than trying to use second-best measures to offset the effects of a given degree of wage rigidity.

The nature of these questions makes it unlikely that they have unambiguous general answers, and we will not attempt to derive answers for very general cases. The main purpose of this paper, instead, is to provide a series of numerical illustrations of the possible welfare effects of second-best tariff pollcy under a variety of assumptions concerning the nature of the wage rigidity, the presence of domestic tax distortions in addition to labour market distortions, and the sectoral mobility or immobility of capital. In addition, we also carry out calculations which illustrate the relative magnitudes of the potential gains from eliminating the wage rigidity itself, and from implementing secondbest commercial policies, respectively. 
The model used is a simple 2-sector model of a small, open economy where prices are given internationally, there are neither transport costs nor nontraded goods, and, with the exception of the market for urban labour, all markets are competitive. The wage in the urban (manufacturing) sector is taken to be determined in a non-competitive fashion, reflecting some combination of government intervention and labour union market power. Following Blomqvist (1979), the urban wage is assumed to change in response to changes in the prices of agricultural and mamufactured goods; we justify this assumption by arguing that the target wage for which the government or labour unions are aiming, is intended to maintain a given real income for urban workers. Though distributional effects may be very important, to keep the analysis simple it is assumed that there is only one type of representative consumer; in other words, these effects are ignored.

To provide a model for our hypothetical economy, we used data from Kenya; we constructed our theoretical model in such a way that the initial solution values for its endogenous variables would correspond to actual data for these variables taken from the economy of Kenya in 1978. In other words, we assumed that these data represented an equilibrium point within the framework of a general equilibrium model. To illustrate the effects of changing commercial policy, and to find the approximate second-best policies, we then computed new model solutions at alternative hypothetical values for the tariff (or import subsidy) on manufactured goods. 
II. The Basic Model

The model is a standard Harris-Todaro formulation of an economy with two sectors, manufacturing and agriculture (indexed by $M$ and $A$ respectively), and two factors of production, capital (K) and labour (L). On the production side we assume constant elasticity of substitution production functions :

$$
Q_{i}=\left[a_{\mathrm{Ii}} \mathrm{L}^{-\rho_{1}}+a_{\mathrm{Ki}} \mathrm{K}^{-\rho_{1}}\right]^{-1 / \rho_{1}} ; \quad i=\mathrm{A}, \mathrm{M},
$$

where $Q_{1}$ is output in the $1^{\text {th }}$ sector, $a_{L i}$ and $a_{K i}$ are parameters, and $\rho_{1}$ is the parameter which determines the elasticity of substitution, $\sigma_{1}$, between the factors of production; we have $\sigma_{i}=1 /\left(1+p_{i}\right)$.

The assumptions of perfect competiton and profit maximization in both markets give the following equilibrium conditions:

$$
\begin{aligned}
& P_{A} a_{I A}\left(\frac{A}{L_{A}}\right)^{1+p_{A}}=w_{A}, \\
& P_{A} a_{K A}\left(\frac{Q_{A}}{K_{A}}\right)^{1+\rho_{A}}=r_{A}, \\
& P_{M}\left(1+t_{M}\right)(1-r) a_{I M}\left(\frac{Q_{M}}{L_{M}}\right)^{1+\rho_{M}}=w_{M^{\prime}}
\end{aligned}
$$

$$
P_{M}\left(1+t_{M}\right)(1-\tau) a_{K M}\left(\frac{Q_{M}}{K_{M}}\right)^{1+p_{M}}=r_{M} \text {, }
$$

where $P_{i}$ are the international prices of the two goods, $w_{i}$ and $r_{i}$ are the rates of return to labour and capital in each sector, $t_{M}$ is the tariff rate, and $T$ is the indirect business tax rate in the manufacturing sector. (We assume throughout that there is no tariff or import subsidy on the agricultural good, and no indirect taxation on agriculture.)

As stated above, the wage in the manufacturing sector, ${ }_{M}$, is taken to depend on the prices of agricultural and manufactured goods, reflecting a target wage which would give the urban worker a constant real purchasing power. In 
alternative versions of the model, we approximate this relationship as a linear function given by (6) or ( $\left.6^{\prime}\right)$

$$
w_{M}=.875 P_{A}+1.654\left(1+t_{M}\right) P_{M}
$$

$$
\mathrm{w}_{\mathrm{M}}=2.86 \mathrm{P}_{\mathrm{A}} \text {. }
$$

In (6), the coefficients for the two prices have been determined on the basis of the shares of agricultural and non-agricultural goods in Kenya's 1978 GDP; in other words, the wage rate is assumed to respond to price changes in such a way that the urban worker can continue to buy a given basket of the two goods with the same composition as GDP. In ( $\left.6^{\prime}\right)$, on the other hand, the wage is supposed to respond to changes in the price of food only. ${ }^{1}$

Equation (7) is the standard Harris-Todaro rural-urban migration equilibrium condition, which states that the agricultural wage equals the mamacturing wage times the probability of having a job in the manufacturing sector:

$$
w_{A}=w_{M}\left(\frac{L_{M}}{L_{U}+I_{M}}\right) \text {, }
$$

where $L_{U}$ is urban unemployment.

In those simulations where capital is assumed to be mobile between sectors, we also have

$$
\mathbf{r}_{\mathrm{A}}=\mathbf{r}_{\mathrm{M}^{\circ}}
$$

The representative consumer's income consists of the returns from capital and labour, ${ }^{2}$ and of transfers from the government; these transfers are assumed equal to total government revenue from tariffs and the indirect business tax, plus the amount of foreign resource inflow:

$$
Y=w_{A} I_{A}+r_{A} K_{A}+w_{M} I_{M}+r_{M} K_{M}+t_{M} P_{M}\left(C_{M}-Q_{M}\right)+\tau P_{M}\left(1+t_{M}\right) Q_{M}+F I,
$$

where FI is the amount of foreign resource inflow that Kenya experienced in 1978, and $C_{i}$ is the total domestic consumption of the $i^{\text {th }}$ commodity.

On the demand side, we assume that the consumer maximizes a utility function given by: 
(10)

$$
U=\sum_{1} m_{1} \log \left(C_{1}^{-\theta_{1}}\right), \quad 1=A, M,
$$

subject to the budget constraint

$$
Y=\sum_{i} P_{i} C_{i}, \quad i=A, M,
$$

where the $\mathrm{m}_{i}$ and $\theta_{i}$ are parameters. Solving this maximization problem will give rise to demand functions forming a linear expenditure system ${ }^{3}$

$$
c_{i}=\theta_{i}+\frac{m_{i}}{P_{i}}(Y-F) ; \quad i=A, M,
$$

where $F=\Sigma P_{i} \theta_{i}$. Note that, by combining (11) and (9), it is possible to obtain the balance of payments constraint, that the value of imports must exceed the value of exports by the amount of the foreign inflow.

Finally, the model is closed by the accounting identity

$$
L_{A}+L_{M}+L_{U}=\bar{L}
$$

where. $\overline{\mathrm{I}}$ is the total amount of labour in the economy, and by either

$$
\mathrm{K}_{\mathrm{A}}=\overline{\mathrm{K}}_{\mathrm{A}}, \mathrm{K}_{\mathrm{M}}=\overline{\mathrm{K}}_{\mathrm{M}}
$$

where overbars denote exogenously given values, for the case where the capital stock in each sector is sector-specific and immobile, or by

$$
\text { (14') } \mathrm{K}_{\mathrm{A}}+\mathrm{K}_{\mathrm{M}}=\overline{\mathrm{K}} \text {, }
$$

where $\bar{K}$ is the total amount of capital in the economy, for the case when capital is considered mobile between the two sectors.

\section{The Simulation Results}

A brief description of the method that we used for assigning values to the model's parameters, via construction of an initial "consistent data set" corresponding to the observed data for the Kenyan economy in 1978, is given in the Appendix to the paper. Given the values of these parameters and of the exogenous variables such as total factor supplies, the foreign capital inflow, and the tax rates, we then constructed a computer algorithm which enabled us to solve for the endogenous variables under varying assumptions. In this section, we present and discuss summary results of these various hypothetical experiments. 
In the first set of simulations, we took the labour market imperfection as given, and investigated the effectiveness of tariff policy as a means of partially offsetting the efficiency loss from this imperfection. We considered a variety of model specifications, resulting from varying combinations of assumptions regarding intersectoral capital mobility, the presence or absence of a tax on the domestic production of manufactured goods, and the way the manufacturing sector wage depends on the price of the agricultural and manufactured good respectively; in addition, we also considered a case in which urban workers not employed in the manufacturing sector could earn an income in the "traditional urban sector". In the second set of simulations, we considered the hypothetical effects of not only using tariff policy but also eliminating the labour market imperfection, as a way of improving resource allocation in the economy.

Because of the complexity of the model, we did not attempt to solve analytically for the precise second-best commercial policy in each case; instead, we simply solved the model for a series of assumed rates of tariff on the manufactured good, ranging from $+50 \%$ to $-50 \%$ (i.e., a $50 \%$ import subsidy) in intervals of 10 percentage points. The tariff or subsidy rates discussed in the following paragraphs merely represent those rates from among the ones investigated that yielded the highest value of the utility function (10), and do not, strictly speaking, represent the precise second-best rates. However, we believe that in general, the rates we computed are close to the second-best ones, and the value of the utility function declined monotonically as we considered tariff or subsidy rates successively further from the one yielding the highest utility. 
The results of the first set of numerical experiments are summarized in Table 1. For each of the experiments numbered 1 to 6 in Table 1 , subcase (a) is the solution when the urban wage is given by (6) above (i.e., depends on the prices of both the agricultural and manufactured goods), while subcase (b) results when the urban wage is fixed in terms of the agricultural good, as in $\left(6^{\prime}\right)$.

a. Wage Distortion, Sector-Specific Capita1

In experiments 1 and 2, we followed Harris and Todaro in assuming that the amount of capital in each of the two sectors was given and fixed. Cases $1 \mathrm{a}$ and $1 \mathrm{~b}$ represent the base simulations in which only the tariff rates were varied, but other parameters (in particular, the rate of indirect business tax) were held at the same values that were used in the Appendix to represent the Kenyan economy in 1978.

In case la, the table shows that the highest value of the objective function was attained at a manufacturing good import subsidy of $20 \%$. This result is consistent with $S B^{\prime}$ 's finding that if the urban wage is rigidly tied to the price of the manufactured good, an import subsidy on this good would increase welfare.

An intuitive interpretation of the $S B$ result is that a fall in the price of the manufactured good (in response to an import subsidy) will, under their specification of the way the urban wage is determined, induce an equiproportional fall in the urban wage. This fall in the urban wage will reduce the relative profitability for a worker to stay in the city looking for a job (even though, under the SB assumption, there would be no reduction in urban employment). Thus, there will be return migration back to agriculture, and hence reduced urban unemployment, and increased agricultural output. With our specification of the determination of the urban wage in case la (i.e., equation (6)), the urban wage 
Table 1

Model Solutions at Approximate Second-Best Tariff Rates, NonCompetitive Urban Labour Market

(1) Tariff Rate:

(2) $I_{M}$

(3) $I_{A}$

(4) $\mathrm{L}_{\mathrm{u}}$

(5) $Y_{w}$

(6) $Y_{W}^{0}$

\begin{tabular}{|c|c|c|c|c|c|c|c|c|c|c|c|}
\hline \multicolumn{2}{|c|}{ Case 1} & \multicolumn{2}{|c|}{ Case 2} & \multicolumn{2}{|c|}{ Case 3} & \multicolumn{2}{|c|}{ Case 4} & \multicolumn{2}{|c|}{ Case 5} & \multicolumn{2}{|c|}{ Case 6} \\
\hline $1 a$ & $1 \mathrm{~b}$ & $2 a$ & $2 b$ & $3 a$ & $3 b$ & $4 a$ & $4 \mathrm{~b}$ & $5 a$ & $5 b$ & $6 a$ & $6 \mathrm{~b}$ \\
\hline-.2 & +.4 & -.3 & 7.1 & \pm .0 & 7.3 & -.3 & -.1 & -.3 & 7.2 &.- .3 & -.1 \\
\hline 77 & 118 & 124 & 145 & 82 & 109 & 124 & 114 & 124 & 163 & 129 & 120 \\
\hline 719 & 556 & 636 & 484 & 686 & 574 & 637 & 559 & 520 & 232 & 494 & 306 \\
\hline 94 & 216 & 130 & 261 & 122 & 207 & 129 & 217 & 246 & 495 & 267 & 464 \\
\hline 1391 & 1372 & 1473 & 1375 & 1377 & 1366 & 1472 & 1367 & 1478 & 1402 & 1481 & 1371 \\
\hline$(1:$ & 0) & (13 & 73) & (136 & & (13. & & (14) & & (1: & 26) \\
\hline
\end{tabular}

\section{Legend :}

Line 1 - Approximate second-best tariff rate.

Iine 2 - Amount of manufacturing labour at this tariff rate.

Line 3 - Amount of agricultural labour.

Iine 4 - Number of urban unemployed.

Iine 5 - Real income at world prices $\left(Q_{M}+Q_{A}\right)$ 。

Iine 6 - Real income at world prices with a tariff rate of $20 \%$ (roughly corresponding to Kenya's actual tariff rate in 1978).

Description of Cases 1 - 6:

Case 1: sector-specific capital, indirect business tax $=.324$

Case 2: sector-specific capital, indirect business $\operatorname{tax}=0$

Case 3: intersectorally mobile capital, indirect business tax $=.324$

Case 4: intersectorally mobile capital, indirect business tax $=0$

Case 5: sector-specific capital, indirect business tax $=0$, productivity of "unemployed" labour $=0.5$ units of agricultural output

Case 6: intersectorally mobile capital, otherwise same as Case 5.

Subcases 1a-6a: $\mathrm{w}_{\mathrm{m}}=.875+1.654 \cdot \mathrm{P}_{\mathrm{m}}$

$1 b-6 b: w_{m}=2.86$

$$
\left(P_{a}=1 \text { throughout }\right) \text {. }
$$

Initial conditions: See Appendix。 
falls less than in proportion to the reduction in the price of the manufactured good when there is an import subsidy. For this reason, there will be some reduction in employment and output in the manufacturing sector. However, due to the drop that does take place in both the urban wage and urban employment, there is strong return migration, less urban unemployment, and increased agricultural output. The migration is strong enough that the increase in agricultural output more than offsets the $108 s$ of manufactured output even though labour is more productive in the mamfacturing sector. Note that it is crucial in this case that all labourers find work in the agricultural sector, and that the marginal product of labour does not fall sharply (as it might, for instance, if a limitation on the amount of agricultural land were to imply sharply diminishing returns to agricultural labour).

In case $1 b$, the urban wage is as sumed to be determined as in equation (6'); that is, it is assumed to be proportional to the price of the agricultural good. The highest level of utility is now attained at a manufactured good tariff of $40 \%$ Because the urban wage rate does not depend on the price of the mamfactured good in this experiment, an increase in the price of the mamfactured good in response to a tariff will lead to a proportional decrease in the wage. rate denominated in terms of the manufactured good; as a result, there will be a large increase in the amount of labour employed in the mamuacturing sector where it is highly productive. The consequent increase in the production of the mamufactured good is more than sufficient to compensate for the decrease in agricultural output, even though some of the labour drawn away from the agricultural sector ends up unemployed.

Comparing cases $1 \mathrm{a}$ and $1 \mathrm{~b}$ provides an illustration of the results derived by Blomqvist (1979): As the non-competitive urban wage moves from being tied primarily to the price of the manufactured good, towards depending more and more 
on the price of the agricultural good, one eventually reaches a point at which the second-best commercial policy changes from an import subsidy to an import tariff. As shown in the Appendix, Kenyan tax policy in 1978 included a relatively high rate of taxation on the manufacturing sector: the average rate of "indirect business taxes" was as high as $32.4 \%$. Clearly, this tax could potentially have a very strong impact on resource allocation in 1978, and could also affect what would be a second-best commercial policy, since existing tax distortions will generally affect the consequences of any policy that changes the pattern of resource allocation in the economy. To investigate the sensitivity of our results to the pattern of domestic taxation, we repeated the same simulation as in case 1 , but on the as sumption that the rate of indirect business tax was zero. The results are reported as cases $2 a$ and $2 b$. In case $2 a$, with the urban wage being determined as in (6), the best commercial policy now involves a $30 \%$ import subsidy, rather than $20 \%$ as in case 1 a; when the wage is fixed in terms of the agricultural good, an import tariff is still indicated as the best policy, but its value falls from $40 \%$ in case $1 b$ to $10 \%$ in case $2 \mathrm{~b}$. The logic of this result is straightforward: when the business tax is removed, there is a tendency for more labour to be transferred into the mamuacturing sector, lowering the marginal productivity there. Because of this lower marginal productivity, the benefit from transferring labour from manufacturing into agriculture via an import subsidy is greater in case $2 a$ than in case 1a. By the same token, the benefit from inducing a labour transfer into the manufacturing sector via an import tariff, as happens in case $2 b$, is smaller than it was in case $1 \mathrm{~b}$ when the business tax had not been removed. As a result, the called-for import subsidy in case $2 a$ is larger than in la, and the second-best import tariff in $2 b$ is smaller than that in $1 b$. 
b. Wage Distortion, Intersectorally Mobile Capital

The results from simulations 3 and 4 can be used to illustrate some of the consequences of intersectoral capital mobility: The only difference between cases 1 and 3 and between 2 and 4, is that capital is assumed intersectorally mobile in 3 and 4, rather than immobile and sector-specific as in 1 and 2. The most interesting pattern that emerges from comparing the result of these simulations is that intersectoral capital mobility appears to reduce the opportunities for using commercial policy as a second-best instrument for offsetting the effects of the labour-market distortion. In case $3 a$, for example, the second-best commercial policy is to reduce the tariff (from its initial value of $20 \%$ ) to zero; but it is not worth going on to an import subsidy as in cases $1 a$ and $2 a$. Intuitively, the reason is that the beneficial effects of using an import subsidy to induce labour to transfer to the agricultural sector, is partially offset by the detrimental effect of the movement of capital into agriculture in response to the reduced price of the manufactured good. A similar argument can be used to explain why the second-best policy in case $3 b$ involves a lower import tariff, and a smaller transfer of labour into the manufacturing sector, than in case $1 \mathrm{~b}$.

Simalation 4 illustrates the second-best commercial policy when there is no indirect business tax and capital is intersectorally mobile. In case 4a, when the wage is determined as in (6), the second-best policy is a $30 \%$ import subsidy on the manufactured good. This is the same as in case $2 a$, and the resulting resource allocation is essentially the same as in case $2 a$ where capital was taken as sector-specific. Case $4 \mathrm{~b}$ is more interesting, however. In this case, with the wage being fixed in terms of the agricultural good, the second-best policy is now an import subsidy of $10 \%$; in the corresponding case with immobile capital, the second-best policy was a $10 \%$ tariff. Again 
the intuition behind this result involves consideration of the transfers of both capital and labour in response to a change in commercial policy. The potential efficiency gain from a non-zero tariff in this case (i॰e,, when the labour market rigidity represents the only distortion) results from its effect on the unemployment rate: By driving up the agricultural wage and hence narrowing the gap between the rural and urban wages, a positive tariff can reduce unemployment. ${ }^{4}$ With mobile capital, the rural wage depends on both the transfer of labour and capital that results from a tariff or import subsidy. But it is easy to show that if the capital-labour ratio in manufacturing exceeds the ratio in agriculture, an import tariff will cause a transfer of resources out of agriculture in such a way that the capitallabour ratio in that sector is reduced; the agricultural wage is consequently reduced. This would tend to increase the equilibrium unemployment rate, causing an efficiency loss instead of a gain. Reversing the argument explains why an import subsidy is the second-best policy in this case. 5

c. Wage Distortion, Non-Zero Labour Productivity in the Informal Sector

In simulations 5 and 6 , we made an attempt to recognize the fact that many of the urban workers who cannot find jobs in the "formal" manufacturing sector will be working in the "informal" urban sector. As data on the unemployed and on informal sector workers are unavailable for the Kenyan case, we will simply assume that: (i) all urban workers who cannot find jobs in the formal sector do find a job in the informal sector; (ii) they each produce a fixed amount of output equal to one-half the original agricultural wage; (iil) they use no capital; and (iv) the good they produce is similar enough to the agricultural sector good so that the two can be lumped together and considered a single good. With the "unemployed" having positive productivity, the migration equilibrium condition ( 7 ) must be modified. It becomes : 


$$
\text { (7') } \frac{I_{M}}{L_{M}+I_{U}} \cdot\left(w_{M}+\frac{0.5 L_{U}}{L_{M}}\right)=w_{A} \text {; }
$$

where $I_{U}$ is now the number of informal-sector workers, and where units were chosen such that the original value of $w_{A}=1$.

The results of these simulations, case 5 with capital assumed immobile and sector-specific and 6 with intersectoral mobility, are most directly comparable with simulations 2 and 4, respectively, since in all these cases the indirect business tax was assumed to be zero.

A pairwise comparison between cases 2 and 5 (with immobile capital) and 4 and 6 (with mobile capital) indicates that the second-best commercial policies remain essentially the same whether or not informal-sector labour is productive; this holds both when the urban wage is assumed fixed in terms of the agricultural good (cases $2 b, 4 b, 5 b, 6 b$ ) or responds to the prices of both goods $(2 a, 4 a, 5 a, 6 a)$. The main difference is the size of the agricultural sector at the second-best commercial policy; when Informal-sector labour is productive, the equilibrium labour allocation to the agricultural sector is much smaller than when urban labour not employed in the formal sector has zero productivity.

\section{d. No Wage Distortion, Competitive Labour Market}

While the results reported in Table 1 are all derived from model solutions when the manufacturing wage is determined in a non-competitive manner, the results for cases $7-10$ reported in Table 2 are derived from solving the model under the assumption that the labour market rigidity has been eliminated and the labour maxket clears at full employment with a common.wage prevailing in the agricultural and manufacturing sectors. 
$\underline{\text { Table } 2}$

Model Solutions at Approximate Second-Best Tariff Rates, Competitive Labour Market

(1) Tariff Rate

(2) $I_{M}$

(3) $I_{A}$

(4) $I_{u}$

(5) $Y_{W}$

(6) $\mathrm{Y}_{\mathrm{W}}^{\mathrm{O}}$

\begin{tabular}{c|c|c|c} 
Case 7 & Case 8 & Case 9 & Case 10 \\
\hline .3 & \pm 0 & $+.4^{*}$ & \pm 0 \\
401 & 460 & 564 & 611 \\
489 & 430 & 326 & 278 \\
- & - & - & - \\
1811 & 1815 & 1883 & 1884 \\
$(1805)$ & $(1806)$ & (1865) & (1868)
\end{tabular}

\section{Legend:}

Line 1 - Approximate second-best tariff rate.

Iine 2 - Amount of manufacturing labour at this tariff rate.

Iine 3 - Amount of agricultural labour.

Iine 4 - Number of urban unemployed.

Line 5 - Real income at world prices $\left(Q_{M}+Q_{A}\right)$

Line 6 - Real income at world prices with a tariff rate of $20 \%$ (roughly corresponding to Kenya's actual tariff rate in 1978).

\section{Description of Cases 7 - 10:}

Case 7: sector-specific capital, indirect business tax $=.324$

Case 8: sector-specific capital, no indirect business tax

Case 9: intersectorally mobile capital, indirect business tax $=.324$

Case 10: intersectorally mobile capital, no indirect business tax

* Export subsidy. 
Perhaps the most noteworthy aspect of the simulation results shown in Table 2 is the way they compare with the results shown in Table 1: The efficiency gains that could have been had if the urban-sector wage rigidity could have been eliminated in 1978 would have been large enough to raise Kenya's real output at world prices from a level around $\{\mathrm{K} 1.3-1.4$ billion, to a level somewhere around $\{\mathrm{KK} 1.8$ - 1.9 billion, according to our model. Compared to this potential gain, the efficiency increases that are possible by moving to a second-best commercial policy without eliminating the wage rigidity, are typically quite small (cf. Iines 5 and 6 in Table 1)。 Another striking aspect of the results in Table 2 is the large equilibrium labour force in the manufacturing sector: In cases 9 and 10, the large labour force in this sector and the movement of capital into manufacturing that would result from eliminating the wage rigidity, are enough to convert Kenya into a net exporter of the manufactured good ${ }^{6}$ The second-best commercial policies In cases 7 and 9, when there is assumed to be an indirect business tax of $32.4 \%$ on the manufactured good, involve tariff (or export subsidy) rates of $30 \%$ or $40 \%$ The intuitive explanation here is simple: With no labour market distortion, the only reason for a non-zero tariff (or export subsidy) is that it can be used to offset the disincentive effect of the indirect tax on mamfacturing production; it is not surprising, therefore, that the second-best rate is close to the domestic tax rate. The "second-best" tariff (or subsidy) rates of zero in cases 8 and 10 simply confirm that for a small country with no labour market, tax, or any other distortion, the optimum commercial policy is free trade; cases 8 and 10 in fact correspond to the firstobest solutions for the cases of sector-specific and intersectorally mobile capital, respectively。 
IV. Conclusions

A model of the Kenyan economy has been used to investigate the nature of second-best commercial policies in a two-sector economy distorted by a rigid urban wage with resulting urban unemployment. The model was solved numerically under varying structural assumptions in order to illustrate the quantitative consequences of different tariff policies for economic welfare. Due to the unreliability or lack of certain key data, and the resulting somewhat arbitrary specification of some of the equations, the results must obviously be interpreted with caution. However, a number of generalizations are suggested by the results. The analysis has shown that whether and to what extent an import tariff is beneficial to an economy with a distortion in the form of a non-competitive manufacturing wage and urban unemployment, depends on the following factors:

(i) Whether the urban wage depends primarily on the price of the agricultural or the manufactured good. The more strongly it depends on the price of the agricultural good, the more likely it is that an import tariff (rather than an import subsidy) is the second-best policy.

(ii) Whether there are other tax distortions in the economy. For example, if there is a production tax on the mamufactured good, the secondbest commercial policy is more likely to involve an import tariff.

(iii) Whether or not capital is intersectorally mobile. In particular, if the capital intensity in manufacturing is higher than that in agriculture, and the urban wage depends strongly on the price of the agricultural good, the second-best commercial policy may involve an import subsidy if capital is intersectorally mobile, even though an import tariff is called for when capital is sector-specific and immobile. 
The potential gains from moving away from Kenya's actual tariff rate of about $20 \%$ in 1978 , to the second-best rate, were typically fairly sma11; in contrast, a comparison between the model solutions with a rigid manufacturing wage on the one hand, and solutions when the overall labour market was assumed to be competitive on the other, showed that the potential gains from reducing or eliminating the labour market distortion itself, might be very substantial. We reiterate again that our results are highly tentative, and to be taken more as quantitative illustrations of the consequences of different kinds of commercial policy under different circumstances, than as a guide to be used directly in formulating actual commercial policy in Kenya. Indeed, the most obvious result of the analysis may be that the present analytical methods and knowledge of the Kenyan economy are insufficient for us to make specific policy recomendations. In particular, more reliable data have to be collected, especially if one wishes to take account of distributional effects of tariff policy (as well as efficiency effects), 8 omething this paper does not do. 


\section{Footnotes}

* We would like to thank Emmanuel Jimenez for helpful comments.

${ }^{1}$ With an initial value of $w_{m}=2.86$, equation (6) implies that the elasticity of the wage rate, with respect to the domestic price of the manufactured good, equals .694 which is the share of the manufactured good in GDP; the elasticity with respect to the price of the agricultural good is $1-.694=.306$, the share of the agricultural good in GDP. In $\left(6^{\prime}\right)$, the latter elasticity equals unity.

2 With perfect competition and constant returns to scale, total factor returns in each sector are equal to the after-tax value of production; there are no residual entrepreneurial profits.

${ }^{3}$ See Taylor (1979, pp. 219-23), for a succinct description of the linear expenditure system.

${ }^{4}$ As explained in Blomqvist (1979, po 152), if the equilibrium unemployment rate stays constant, the higher marginal productivity of labour in the mamfacturing sector is precisely offset by the fact that an additional urban job causes more than one worker to be withdrawn from agriculture, so that there is no net efficiency gain from transferring labour unless the unemployment rate falls.

5 The fact that an import tariff is the second-best policy in case $3 b$ is presumably due to the fact that the unfavourable impact of a tariff on the unemployment rate is more than counterbalanced by its favourable effect of partially offsetting the impact of the distortionary business tax.

${ }^{6}$ The "tariff" rate of $t_{0} 4$ shown in line 1 thus has to be interpreted as an export subsidy rather than an import tariff. 


\section{References}

BIomqvist, A. G. (1979), "Urban Unemployment and Optimal Tax Policy in a Sma11, Open Dual Economy," Journal of Development Studies, Vol. 15, No. 2, pp. 147-164.

Harris, J. R. and M. P. Todaro (1970), "Migration, Unemployment and Development: A Two-Sector Analysis," American Economic Review 60, March, pp. 126-142.

Srinivasan, T. N., and J. N. Bhagwati (1975), "Alternative Policy Rankings in a Large Open Economy with Sector-Specific Minimum Wages," Journal of Economic Theory 11, December, pp. 356-371 .

Taylor, Lance (1979), Macro Mode1s for Developing Countries, New York: McGraw-Hi11.

Todaro, M. P. (1969), "A Model of Labor Migration and Urban Unemployment in Less Developed Countries," American Economic Review 59, March, pp. 138-148 


\section{Appendix}

To run the computable general equilibrium model a consistent data set has to be constructed for the Kenyan economy of 1978. The main features of a consistent data set for an open economy are that: (I) any excess demands are imported or excess supplies are exported; (ii) the surplus of imports over exports equals the exogenous foreign inflow; and (iii) the government budget is in balance with all receipts being transferred back to consumer groups who then spend it. The consistent data set used in this paper was constructed by McMahon on the basis of material assembled during his stay in Kenya in 1980. In this Appendix, we confine ourselves to outlining the general procedures used in constructing the data set; further details on exact data sources and assumptions used are available from McMahon.

Units of labour and capital were chosen such that $w_{a}=1, r_{a}=r_{m}=1$. The Initial value of the manufacturing sector wage was estimated at $w_{m}=2.86$. Units of output were chosen so that the world prices of both were equal to unity; with a $20 \%$ tariff on the manufactured good, the initial domestic price of that good was $P_{m}=1.2$.

The initial values for the model's endogenous variables are shown in Panel I of Table AI, while Panel II gives the assumed values of some of the model parameters; Panel III, finally, gives the values of those parameters that were solved for using the restrictions of the model together with the known initial values of the endogenous variables and the assumed parameters. 
Table Al

$\begin{array}{lcc}\text { I. Initial Values of Model Variables } & \text { II. Assumed Parameter Values } \\ \text { Tariff rate: } & +.2 & \rho_{M}=+.33 \\ I_{M} & 94.9 & \rho_{A}=+.33 \\ I_{A} & 618.3 & m_{M}=.755 \\ I_{U}^{1} & 176.5 & m_{A}=.245 \\ K_{M} & 293.3 & \text { Foreign Capital Inflow: } 237.6^{2} \\ K_{A} & 47.6 & \\ Q_{M} & 695.8 & \\ Q_{A} & 665.9 & \\ C_{M} & 1130.7 & \\ C_{A} & 468.6 & \end{array}$

$\begin{array}{cr}\text { III. Computed } & \text { Parameter Va } \\ a_{L M} & .2491^{3} \\ a_{\mathrm{KM}} & .3908^{3} \\ a_{I A} & .9061^{3} \\ a_{\mathrm{KA}} & .0299^{3} \\ \theta_{\mathrm{M}} & 556.44^{4} \\ \theta_{\mathrm{A}} & 244.97^{4}\end{array}$

Notes: 1. $I_{f}$ was estimated residually using equation (7) together with the known values of $\mathrm{w}_{A}, \mathrm{w}_{\mathrm{M}}$, and $\mathrm{L}_{\mathrm{M}^{\circ}}$

2. Foreign capital inflow equals consumption at world prices less production at world prices.

3. Computed from conditions (2) - (5) together with the known initial quantities of outputs, inputs, and factor returns.

4. Computed by assuming that initially $F=P_{M} \theta_{M}+\theta_{A}=0.5\left(P_{M} C_{M}+C_{A}\right)$, then solving for $\theta_{M}$ and $\theta_{A}$ using (12) together with the known. values of the $m_{i}, C_{1}$, and $P_{1}$. See Taylor (1979, pp. 220-221). 


\author{
$8101 C$ \\ $8102 \mathrm{C}$ \\ $8103 C$ \\ $8104 \mathrm{C}$ \\ $8105 \mathrm{C}$ \\ $8106 C$ \\ $8107 \mathrm{C}$ \\ $8108 C$ D gJ \\ 8109C D SU \\ $8110 \mathrm{C}$ \\ $8111 \mathrm{C}$ \\ Freid, Joel and Peter bowitt Why Inflation Reduces Real Interest Rates \\ Markusen, James R. Factor Movements and Commodity Trade as Compliments: \\ A survey of some Cases. \\ Conlon, R.M. Comparison of Australian and Canadian Manufacturing \\ Industries: Some Empirical Evidence. \\ Conlon, R.M. The Incidence of Transport cost and Tariff Protection: \\ Some Australian Evidence. \\ Laidler, David. On the Case for Gradualism. \\ Wirick, Ronald G. Rational Expectations and Rational \\ Stabilization Policy in an Open Economy \\ Mansur, Ahsan and John Whalley Numerical Secification of Applied \\ General Equilibrium Models: Estimation, Calibration, and Data. \\ Burgess, David F., Energy Prices, Capital Formation, and Potential GNP \\ Jimenez, E. and Douglas H Keare. Housing Consumption and Income in \\ the Low Income Urban Setting: Estimates from Panel Data in El Salvador \\ Whalley, John Labour Migration and the North-South Debate \\ Manning, Richard and John McMillan Government Expenditure and \\ Comparative Advantage
}

$\underline{1982}$

$8201 C$

Manning, Richard and James R. Markusen Dynamic Non-gubstitution and Long Run Production Possibilities

$8202 C$

Feenstra, Robert and Ken Judd Tariffs, Technology Transfer, and Welfare

$8203 C$

Ronald W. Jones, and Douglas D. Purvis: International Differences in Response to Common External gocks: The Role of Purchasing Power Parity

$8204 C$

James A Brander and Barbara J. Spencer: Industrial strategy with Committed Firms

$8205 C$

Whalley, John, The North-South Debate and the Terms of Trade: An Applied General Equilibrium Approach

$8206 C$

Roger Betancourt, Christopher Clague, Arvind Panagariya CAPI TAL UII IIZATI ON IN GENERAL EQUIIIBRI UM

$8207 \mathrm{C}$

Mansur, Ahsan $H_{6}$ On the Estimation of Import and Export Demand Elasticities and Elasticity Pessimism.

$8208 \mathrm{C}$

Whalley, J, and Randy Wigle PRICE AND QUANTITY RIGIDITIES IN ADJUSTMENT TO TRADE POLICY CHANGES: ALTERNATIVE FORMULATIONS AND INITIAL CALCULATIONS

8209C DSU Jimenez, E. SQUATTING AND COMMUNITY ORGANIZATION IN DEVELOPING COUNTRIES : A CONCEPTUAL FRAMEWORK 
8:L10C Grossman, G.M. INTERNATIONAL COMPETITION AND THE UNIONIZED SECTOR

8211C LaIdler,D. FRIEDMAN AND SCHWARTZ ON MONETARY TRENDS - A REVIEW ARTICLE

8212C Imam, M.H. and Whalley, J. INCIDENCE ANALYSIS OF A SECTOR SPECIFIC MINIMUM

8213C Markusen, J.R. and Melvin, J.R. THE GAINS FROM TRADE THEOREM WITH INCREASING
RETURNS TO SCALE. 8214C INDUSTRIAL ORGANIZATION AND THE GENERAL EQUILIBRIUM COSTS OF PROTECTION IN
SMALL OPEN ECONOMIES.

8215C Laidler, D. DID MACROECONOMICS NEED THE RATIONAL EXPECTATIONS REVOLUTION?

8216C Whalley, J. and Wigle, R. ARE DEVELOPED COUNTRY MULTILATERAL TARIFF REDUCTIONS NECESSARILY BENEFICIAL FOR THE U.S.?

8217C Bade, R, and Parkin, M. IS STERLING M3 THE RIGHT AGGREGATE?

8218C Kosch, B. FIXED PRICE EQUIIIBRIA IN OPEN ECONOMIES.

\section{3}

8301C Kimbell, L.J. and Harrison, G.W. ON THE SOLUTION OF GENERAL EQUILIBRIUM
MODELS.

8302C Melvin, J.R. A GENERAL EQUILIBRIUM ANALYSIS OF'.CANADIAN OIL POLICY.

8303C Markusen, J.R. and Svensson, L.E.0. TRADE IN GOODS AND FACTORS WITH INTERNATIONAL DIFFERENCES IN TECHNOLOGY.

$8304 \mathrm{C}$ Mohammad, S. Whalley, J. RENT SEEKING IN INDIA: ITS COSTS AND POLICY
SIGNIFICANCE.

8305C DSU Jimenez, E. TENURE SECURITY AND URBAN SỌUATTING.

8306C Parkin, M. WHAT CAN MACROECONOMIC THEORY TELL US ABOUT THE WAY DEFICITS
SHOULD BE MEASURED.

8307C Parkin, M. THE INFLATION DEBATE: AN ATTEMPT TO CLEAR THE AIR.

8308C Wooton, I. LABOUR MIGRATION IN A MODEL OF NORTH-SOUTH TRADE.

8309C Deardorff, A.V. THE DIRECTIONS OF DEVELOPING COUNTRIES TRADE: EXAMPLES
FROM PURE THEORY. 8310C Manning, $R$. ADVANTAGEOUS REALLOCATIONS AND MULTIPLE EQUILIBRIA: RESULTS
FOR THE THREE-AGENT TRANSFER PROBLEM. 
$8311 C$ DSU Mohammad, S. and Whalley, J. CONTROLS AND THE INTERSECTORAL TERMS OF TRADE IN INDIA.

8312C Brecher, Richard A. and Choudhr1, Ehsan U. NEW PRODUCTS AND THE FACTOR CONTENT OF INTERNATIONAL TRADE.

8313C Jones, R.W., Neary, J.P. and Ruane, F.P. TWO-WAY CAPITAL FLOWS: CROSSHAULING IN A MODEL OF FOREIGN INVESTMENT.

$8314 C$ DSU Follain, J.R. Jr. and Jimenez, E. THE DEMAND FOR HOUSING CHARACTERISTICS IN DEVELOPING COUNTRIES.

8315C Shoven, J.B. and Whalley, J. APPLIED GENERAL EQUILIBRIUM MODELS OF TAXATION AND INTERNATIONAL TRADE.

8316C Boothe, Paul and Longworth David. SOME IRREGULAR REGULARITIES IN THE CANADIAN/U.S. EXCHANGE MARKET.

8317C Hamilton, Bob and Whalley, John. BORDER TAX ADJUSTMENTS AND U.S. TRADE.

8318C Neary, J. Peter, and Schwelnberger, Albert G. FACTOR CONTENT FUNCTIONS AND THE THEORY OF INTERNATIONAL TRADE.

8319C Veall, Michael R. THE EXPENDITURE TAX AND PROGRESSIVITY.

8320C Melvin, James R. DOMESTIC EXCHANGE, TRANSPORTATION COSTS AND INTERNATIONAL TRADE.

8321C Hamilton, Bob and Whalley, John. GEOGRAPHICALLY DISCRIMINATORY TRADE ARRANGEMENTS .

8322C Bale, Harvey Jr. INVESTMENT FRICTIONS AND OPPORTUNITIES IN BILATERAL U.S.-CANADIAN TRADE RELATIONS.

8323 Wonnacott, R.J. CANADA-U.S. ECONOMIC RELATIONS--A CANADIAN VIEW.

8324C Stern, Robert M. U.S.-CANADIAN TRADE AND INVESTMENT FRICTIONS: THE U.S.: VIEW.

8325C Harrison, Glenn; H. and Kimbel1, Larry, J. HOW ROBUST IS NUMERICAL GENERAL EQUILIBRIUM ANALYSIS?

8326C Wonnacott, R.J. THE TASK FORCE PROPOSAL ON AUTO CONTENT: WOULD THIS SIMPLY EXTEND THE AUTO PACT, OR PUT IT AT SERIOUS RISK?

8327C Bradford, James C. CANADIAN DEFENCE TRADE WITH THE U.S. Conklin, David. SUBSIDY PACTS.

Rugman, Alan M. THE BEHAVIOUR OF U.S. SUBSIDARIES IN CANADA:

IMPLICATIONS FOR TRADE AND INVESTMENTS. 
8328C Boyer, Kenneth D. U.S.-CANADIAN TRANSPORTATION ISSUES.

8329C Bird, Richard M. and Brean, Donald J.S. CANADA-U.S. TAX RELATIONS: ISSUES AND PERSPECTIVES.

8330C Moroz, Andrew R. CANADA-UNITED STATES AUTOMOTIVE TRADE AND TRADE POLICY ISSUES.

8331C Grey, Rodney de C. and Curt1s, John. INSTITUTTONAL ARRANGEMENTS FOR U.S.-CANADIAN NEGOTIATIONS. PART I: CANADA-U.S. TRADE AND ECONOMIC ISSUES: DO WE NEED A NEW INSTITUTION? PART II: INSTITUTIONAL ARRANGEMENTS FOR MANAGING THE CANADA-U.S. ECONOMIC RELATIONSHIP.

$\underline{1984}$

8401C Harrison, Glenn W. and Manning, Richard. BEST APPROXIMATE AGGREGATION OF INPUT-OUTPUT SYSTEMS.

8402C Parkin, Michael. CORE INFLATION: A REVIEW ESSAY.

8403C Blomqvist, Áke, and McMahon, Gary. SIMULATING COMMERICAL POLICY IN A SMALL, OPEN DUAL ECONOMY WITH URBAN UNEMPLOYMENT: A GENERAL EQUILIBRIUM APPROACH. 